\title{
Species Ecological Strategy and Soil Phosphorus Supply Interactively Affect Plant Biomass and Phosphorus Concentration
}

\section{Iris Moeneclaey ( $\square$ iris.moeneclaey@ugent.be )}

Ghent University: Universiteit Gent https://orcid.org/0000-0003-0538-5002

\section{Stephanie Schelfhout}

HOGENT University of Applied Sciences and Arts

\section{Margot Vanhellemont}

Ghent University

\section{Eva DeCock}

Ghent University: Universiteit Gent

\section{Frieke Van Coillie}

Ghent University

\section{Kris Verheyen}

Ghent University

\section{Lander Baeten}

Ghent University

\section{Research Article}

Keywords: Semi-natural grassland, phosphorus, CSR theory, StrateFy, luxury consumption, dilution effect

Posted Date: June 9th, 2021

DOl: https://doi.org/10.21203/rs.3.rs-565483/v1

License: (9) (i) This work is licensed under a Creative Commons Attribution 4.0 International License. Read Full License 


\section{Abstract}

\section{Background and aim}

Excess soil phosphorus often constrains ecological restoration of degraded semi-natural grasslands in Western-Europe. Slow-growing species, often target for restoration, are at a disadvantage because they are outcompeted by fast-growing species. Gaining insight into the responses of plant species and communities to soil phosphorus availability will help understanding restoration trajectories of grassland ecosystems.

\section{Methods}

We set up a pot experiment using twenty grassland species with contrasting growth forms (i.e. grasses versus forbs) and nutrient use strategies (i.e. acquisitive versus conservative nutrient use). We quantified the nutrient use strategy of a species based on the stress-tolerance value of the CSR framework (StrateFy, Pierce et al. 2017). We grew these species as monocultures and in mixtures along a soil phosphorus gradient and measured the aboveground biomass and plant phosphorus concentrations.

\section{Results}

We found plant phosphorus to increase with soil phosphorus supply, but observed no biomass response. Forbs had higher plant phosphorus concentrations compared to grasses both in monocultures and mixtures. The species' nutrient use strategy had contrasting effects on plant tissue phosphorus concentrations, depending on the amount of phosphorus supply (interaction effect) and the biomass of the vegetation (dilution effect). Species with conservative nutrient use strategies survived and even thrived in under excess soil phosphorus availability.

\section{Conclusion}

Our findings contribute to the knowledge required for successfull ecological restoration of species-rich grasslands. Adopting a trait-based approach enabled us to link findings from comparative ecological studies with insights from (eco)physiological research.

\section{Introduction}

Nutrient enrichment is one of the main drivers of the degradation of semi-natural grasslands in Western Europe (Janssens et al., 1998; Klaus et al., 2011; Pywell et al., 2007). Increased soil nutrient availability causes a decline in plant species richness because it promotes a few fast-growing species that monopolise light and outcompete slow-growing species (Hautier et al., 2009) and it reduces niche dimensionality and thus opportunities for many species to co-exist (Harpole \& Tilman, 2007). Ecological restoration of degraded grasslands hence involves lowering the soil nutrient availability (Marrs, 1993), often by extracting nutrients with plant biomass by reinstating a no-fertilization mowing management (Walker et al., 2004). For many specialist and endangered species, limiting phosphorus availability is key 
(Ceulemans et al., 2011; Fujita et al., 2014; Janssens et al., 1998; Wassen et al., 2005). However, phosphorus removal may take decades as phosphorus is a persistent element in the soil that represents long-lasting legacies of past fertilization (Dupouey et al., 2002; Schelfhout et al., 2017). Insight into the response of plant species and communities to soil phosphorus availability will help in understanding restoration trajectories of grassland ecosystems.

Plants use phosphorus for growth by building it into nucleic acids, but species differ in their ability to acquire, use and conserve nutrients (Reich et al., 2003). Generally, graminoids have lower tissue phosphorus concentrations compared to forbs (Güsewell, 2004), because leaf growth in grasses is localised in the basal meristems, which reduces phosphorus requirements for nucleic acids in the remaining part of the leaf (Halsted \& Lynch, 1996). The leaf economic spectrum, which runs from fast to slow return on investments of nutrients and dry mass in leaves, classifies species along a resourceacquisition versus resource-conservation gradient (Díaz et al., 2016; Reich, 2014; Wright et al., 2004). High leaf nutrient concentrations are associated with the acquisitive side of the spectrum. Species exhibiting acquisitive traits, such as fast aboveground growth and short-lived tissues (i.e., high specific leaf area and low leaf dry matter content), are assumed to grow best when resources are abundant. Their high relative growth rate is positively correlated with a high concentration of phosphorus-rich ribosomal RNA required for growth, which explains their high tissue phosphorus concentrations (also referred to as the 'growth rate hypothesis'; Elser et al., 2010; White \& Hammond, 2008). On the other side of the spectrum, we find species with lower potential relative growth rates that are characterized by structurally tougher tissues (i.e. low specific leaf area and high leaf dry matter content) containing less nutrients. The species that exhibit conservative traits, tend to internally recycle nutrients and dominate in vegetation on oligotrophic soils (Dayrell et al., 2018; Lambers \& Poorter, 1992).

Next to the species characteristics, the amount of phosphorus available in the soil may also determine the plant responses. High soil phosphorus availability may lead to increased phosphorus uptake by the plant and hence higher tissue phosphorus concentrations. Alternatively, the extra phosphorus can also be used for increased biomass production, and such growth response leads to a dilution of phosphorus in the tissue (the 'dilution effect', Jarrell \& Beverly, 1981). On the other hand, plants are also able to store a surplus of phosphorus in their tissue that they do not need for biomass production ('luxury consumption', Chapin et al., 1990). The role of this surplus phosphorus is yet debated (Ågren, 2008).

In order to understand the plant-ecological basis for the linkages between soil phosphorus supply, plant tissue phosphorus concentrations and aboveground biomass production in plant species and communities, we set up a pot experiment with twenty grassland species having contrasting growth forms (i.e., grasses versus forbs) and nutrient use strategies (i.e., acquisitive versus conservative). We grew the species as monocultures and in 4-species mixtures along a soil phosphorus gradient. We hypothesized that plant phosphorus concentrations and aboveground biomass increase with increasing soil phosphorus supply, yet depending on the species' identity (i.e., growth form and nutrient use strategy). We expected (1) higher plant phosphorus concentrations in forbs compared to grasses and (2) higher plant phosphorus concentrations in acquisitive species compared to conservative species (3) higher biomass 
in acquisitive species compared to conservative species and (4) a trade-off between the responses of tissue phosphorus concentration and aboveground biomass, with species responding with growth to increasing soil phosphorus supply having lower tissue phosphorus concentrations because of a dilution effect.

\section{Material And Methods}

\section{Plant species}

We selected twenty grassland species naturally occurring in mesotrophic grasslands (Arrhenaterion grassland, European habitatcode 6510). Species were selected according their growth form (10 grasses and 10 forbs) and variation in nutrient use strategy. We ranked the species along a continuous gradient from acquisitive to conservative nutrient use, using the species' stress-tolerance (S) value as a proxy, following the CSR plant strategy scheme (sensu Grime, 1977). We extracted the species' stress-tolerance values ( $S=0-67.5)$ from the StrateFy database (Pierce et al., 2017), which quantifies CSR plant strategies based on leaf traits. Species with a high stress-tolerance value represent a conservative nutrient use strategy, and have a low specific leaf area and high leaf dry matter content. With this species pool, we established monocultures and mixtures of four species covering a gradient in nutrient use strategies. The full species list with stress-tolerance value can be found in the supplementary (fig. S1.4).

We purchased seeds via Rieger-Hofmann GmbH (Germany) and Cruydt-Hoeck (the Netherlands) and germinated them on watered glass beads in a climate chamber, with the temperature and light regime optimised for each species' requirements (see Grime et al., 1981). We sowed slow and irregular germinators earlier than fast germinators to have equally sized seedlings for all species at the time of planting.

\section{Phosphorus treatment}

We filled pots $(5 \mathrm{I}, 23 \times 17 \mathrm{~cm})$ with a potting medium consisting of $1 / 5$ coarse Rhine sand and $4 / 5$ phosphorus poor sandy loamy soil (bioavailable phosphorus ca. $7 \mathrm{mg} / \mathrm{kg}$ soil). At the bottom of the pot, we placed a small piece of cloth to prevent plant roots from escaping and soil from leaking out and a small layer of lightweight expanded clay aggregate to ensure proper drainage (see fig. S1.1). We added different amounts of $\mathrm{NaH}_{2} \mathrm{PO}_{4}$ to the soil to create a phosphorus gradient. The soil phosphorus supply levels ( $\mathrm{P} 0$ to $\mathrm{P} 4$ ) ranged from no phosphorus supply, aiming to have soil phosphorus limitation, to an excess supply of phosphorus, with small intervals between levels at the beginning of the gradient and larger intervals at the end, i.e., adding 0, 25, 41, 145, $303 \mathrm{mg} \mathrm{P} / \mathrm{kg}$ soil. Since not all of the soil phosphorus added to the pots will be available for plant growth, we also measured the bioavailable fraction as Olsen $P$ in each pot at the end of the experiment (Table S1.7).

\section{Experimental setup}

For the monocultures, we replicated each species two times per phosphorus supply level ( $5 \mathrm{P}$ levels $\times 20$ species $\times 2$ replicates $=200$ pots). For the mixtures, we created 40 communities representing different 
species compositions ( $5 \mathrm{P}$ levels $\times 40$ communities $=200$ pots). For creating the 40 communities, we used the following principles: (1) each community contained two grasses and two forbs, (2) species were selected to maximise variation in the community-level stress-tolerance value, (3) all species were equally represented across communities. We had communities with only species with low stress tolerance values, communities mixing species with low and high stress tolerance values, and communities with only species with high stress tolerance values (range of mean $S$ across the communities $=1.4-55.9$ ).

We planted the monocultures in May 2019 and the mixtures in June 2019. Seedlings were planted in a regular pattern and at equal distances to one another, so that plant densities were equal across pots. The exact planting scheme can be found in the supplementary information (fig S1.2). For the mixtures, we planted each of the four species in two patches of four seedlings and assured that every species neighbored all the other species and was equally present in the middle of the pot as at the borders compared to the other species. The same planting density was used for monocultures and mixtures. The mortality of seedlings was overall low, but dead individuals were replaced within the first month after planting.

Pots were placed randomly on tables in the greenhouse and watered ad libitum with a combination of irrigation and hand watering (i.e. checked two times a week, combination of minimum irrigation and hand watering for the most evaporating species/communities). The plants received an optimal light regime prior to harvest. Since the focus of the experiment is on the phosphorus treatment, the pots received rather conservative nitrogen and potassium fertilisation treatments $\left(\mathrm{NH}_{4} \mathrm{NO}_{3}\right.$ and $\left.\mathrm{KNO}_{3}-50 \mathrm{~kg} \mathrm{~N} / \mathrm{ha}\right)$. The monocultures received this fertilisation one time and the mixtures three times prior to the biomass harvests (see supplementary table S1.6). This conservative fertilisation treatment lead to nitrogen limitation in the four highest phosphorus supply levels (P1-P4) as indicated by the N:P ratio that was lower than 10 (Güsewell, 2004) (see supplementary fig S2.1).

\section{Measurements}

The biomass harvest took place at peak biomass, in November 2019 for the monocultures and in June 2020 for the mixtures. For each pot, all aboveground biomass was cut at 2-3 cm above the soil surface, dried to constant weight at $70^{\circ} \mathrm{C}$ for $48 \mathrm{~h}$, weighed and then ground. We measured the total aboveground biomass (g dry mass) per pot for the monocultures and separately measured the biomass of each of the four species in a mixture pot. Plant phosphorus concentration (\%) was measured at the pot level in both monocultures and mixtures. Plant phosphorus concentration was obtained after digesting $100 \mathrm{mg}$ of the sample with $0.4 \mathrm{ml} \mathrm{HClO}_{4}(65 \%)$ and $2 \mathrm{ml} \mathrm{HNO}_{3}(70 \%)$ in Teflon bombs at $140^{\circ} \mathrm{C}$ for $4 \mathrm{~h}$. Phosphorus was measured colorimetrically according to the malachite green procedure (Lajtha et al., 1999).

\section{Data analyses}

All variables were expressed at the pot level: the two continuous response variables, i.e., plant phosphorus concentration (\%) and plant biomass (g), the two design variables, i.e., soil phosphorus supply (mg P / kg soil) and the stress tolerance value expressing the species' or mixture's ecological resource-use strategy. 
Soil phosphorus supply, i.e., the amount of phosphorus added to a pot, was treated as a continuous variable. For the monocultures, the pot-level stress tolerance value was simply the stress tolerance value of the species growing in the pot. For the mixtures, we calculated the community-weighted mean stress tolerance value per pot by using the biomass of each species in the pot as weighting factor, i.e. multiplying each species' proportional biomass (biomass of the species divided by the biomass of the total mixture) with the species' stress tolerance value and calculate the mean of these stress tolerance values of all four species present in the community. In addition, we calculated the proportion of grasses (\% grasses) in each mixture to differentiate between forb-dominated vs. grass-dominated communities by dividing the biomass of the grasses by the total biomass of the mixture.

We fitted separate models for monocultures and mixtures. To check for the effect of growth form (grass vs forb), we fitted separate models for grass and forb monocultures ( $n=100$ pots for grasses, $n=100$ pots for forbs) and included the proportion of grasses in the models for the mixtures when analysing the mixtures $(n=200$ pots). The design variables were included as explanatory variables in the models. For the models with plant phosphorus concentration as a response variable, we included soil phosphorus supply as a linear and a quadratic term because we expected plant phosphorus concentration to saturate at higher soil phosphorus levels. For the biomass response models, soil phosphorus supply was fitted as a linear term as we did not expect a saturating relationship. To check for an effect of biomass on plant phosphorus concentration, i.e., a dilution effect, we fitted and compared the plant phosphorus response model with and without plant biomass as a covariate. We show the models with plant biomass in the result section as these models yielded the highest fit (see supplementary table S3.2). We also included a two-way interaction between soil phosphorus supply and $S$ value to test whether the rate of change in plant phosphorus concentration with soil phosphorus varied with $S$ value. To account for the nonindependence between pots containing the same species or community, we included the identity of the species $(n=20)$ or community $(n=40)$ as random effects in the monoculture or mixture models. We applied linear mixed-effect models (Zuur et al., 2009) using the function Imer in the package Ime4 (Bates et al., 2015). Model predictions were made with the function effect in the package effects (Fox \& Weisberg, 2019)

In the end, we fitted six models, i.e., a model for each of the two response variables (plant phosphorus concentration and plant biomass) and for grass monocultures, forb monocultures and mixtures. We determined the model fits by calculating the coefficient of determination $\left(R^{2}\right)$, the proportion of variance explained by the fixed effects (marginal $R^{2}$ ) and both fixed and random effects (conditional $R^{2}$ ). The Rsyntax for all models can be found in the supplementary information (table S3.1). All data analysis was done in R version 4.0.4 (R Core Team, 2021); graphs were made with ggplot 2.0 (Wickham, 2016).

As we are principally interested in general patterns related to species nutrient use strategy, we only show how plant phosphorus concentration and plant biomass vary with $S$ values in the main text, i.e. not how individual species or communities differ. However, we also explored species-specific patterns in the monocultures for the relationship between the two response variables (i.e. plant phosphorus concentration and plant biomass) and soil phosphorus supply. We modelled these relationships with 
generalised additive models (GAM) as we expected different forms of non-linearities in these relations, depending on the species (see supplementary fig S2.2).

\section{Results}

\section{Plant phosphorus $(\mathrm{P})$ concentration response}

Overall model fit was high $\left(\mathrm{R}^{2} \mathrm{C}=0.86,0.82\right.$ and 0.86 for grass monocultures, forb monocultures and mixtures, see supplementary table S3.3). In both monocultures and mixtures, plant $\mathrm{P}$ concentration increased with increasing soil P supply, and this relation saturated at higher soil P supply levels (Fig. 1a and 2ab). Forbs had higher plant P concentrations than grasses (Fig. 1a; supplementary fig. S2.3), and forb-dominated mixtures had higher plant $P$ concentrations than grass-dominated mixtures (Fig. $2 b$ ). In both the grass and forb monocultures, the $S$ value and soil $P$ supply interactively affected plant $P$ concentration (supplementary table S3.3). At low and high soil $P$ levels, all grasses had similar plant $P$ concentrations. At intermediate $P$ levels, acquisitive grasses (with low $S$ ) had the highest plant $P$ concentration (Fig. 1A left). Conservative forbs (with high $S$ ) showed a stronger increase in plant $P$ concentrations with increasing soil $P$ supply than acquisitive forbs (with low S; Fig. 1a right). In the mixtures, no such interactive effect between the community-weighted mean $S$ value and soil $P$ supply was found (Fig. 2a). Adding biomass as a covariate increased the model fits substantially (supplementary table S3.2). Plant biomass was found to have a highly significant and negative effect on plant $\mathrm{P}$ concentration, i.e. species or mixtures with high biomass had lower plant $\mathrm{P}$ concentrations (supplementary table S3.3).

\section{Plant biomass response}

In general, grasses had a higher biomass than forbs (Fig. 1a and fig. S2.3), and grass-dominated mixtures had a higher total biomass than forb-dominated mixtures (Fig. 2b). Monoculture biomass showed no relation with soil $\mathrm{P}$ supply or species' $\mathrm{S}$ value (Fig. 1b); almost all variation in monoculture biomass was explained by the species identity, for grasses $\left(R^{2} m=0.02\right.$ and $\left.R^{2} c=0.85\right)$ as well as forbs $\left(R^{2} m=0.01\right.$ and $R^{2} c=0.80$; see supplementary table $\left.S 3.4\right)$. The mixture biomass response to soil $P$ supply depended on the community-weighted mean $S$ value; mixtures with a high $S$ value had a higher total biomass at high soil P levels compared to communities with a low $S$ value (Fig. $2 b$ ). Yet, the overall model fit was relatively low $\left(R^{2} m=0.24\right.$ and $\left.R^{2} c=0.31\right)$.

\section{Discussion}

Variation in tissue nutrient concentrations and aboveground biomass is expected to be determined by a combination of soil nutrient availability and species-specific differences in growth form, physiology and life history (Aerts \& Chapin, 1999). Here, we studied how different types of species and communities respond to soil phosphorus supply in regard to tissue phosphorus concentrations and aboveground biomass. Plant phosphorus concentration consistently increased with increasing soil phosphorus supply, in both monocultures and mixtures. No parallel increase in aboveground biomass occured, except for the 
conservative communities. In accordance with our initial expectations, forbs growing in monoculture and communities dominated by forbs had higher tissue phosphorus concentrations compared to grasses growing in monoculture and communities dominated by grasses. The species' nutrient use strategy had contrasting effects on plant tissue phosphorus concentrations, depending on the amount of phosphorus supply (interaction effect) and the biomass of the vegetation (dilution effect).

\section{Increase in plant phosphorus concentration, but no biomass response}

Contrary to what we expected, species did not show a biomass response when we substantially increased the availability of an important nutrient, from concentrations that are generally limiting (ca. $7 \mathrm{mg} / \mathrm{kg}$ Olsen P) to levels that are 4.5 times higher (ca. $32 \mathrm{mg} / \mathrm{kg}$ ). We especially expected the acquisitive, fastgrowing species to show a strong biomass response to increased soil phosphorus supply as these species are assumed to grow best when resources are abundant and fast aboveground growth is one of their main attributes. One possible explanation for the lack of biomass response in our experiment could be nitrogen limitation, despite the fertilization. The observation that only the conservative communities showed a biomass response to soil phosphorus supply, is consistent with this idea. Communities consisting of species exhibiting conservative nutrient use may have overcome the nitrogen limitation because they are able to access alternative forms of nitrogen (e.g., inorganic nitrogen) or don't need that much nitrogen because of internal reuse (i.e., conservative use of nitrogen). An alternative explanation is related to the timing of biomass harvest as our results represent only a snapshot in the growing season of the community and not the productivity of the community over the entire growing season. The data in the present study are from the second cut of the growing season, in June 2020 (the first maintenance cut occurred in April 2020). It is possible that the acquisitive species had used relatively more of the resources for the first spring growth compared to the conservative species (we saw several of the acquisitive species having flowers and even seeds in early April) and that conservative species had a better regrowth compared to the acquisitive species, because they have more belowground biomass sustaining vital regrowth. This finding is also observed in other pot experiments (Güsewell, 2004 and reference therein).

Although our plants showed no biomass response with increasing phosphorus supply, we did observe an increase in plant phosphorus concentration in all study species and communities, which means that plants took up more phosphorus than they actually used to grow. The storage of a surplus in nutrients, in excess of immediate need for growth, is often referred to as luxury consumption (Chapin et al., 1990) or the more neutral term excess uptake (Ågren, 2008). In general, luxury consumption is mostly found in slow-growing, conservative plant species, as fast-growing, acquisitive species principally use the available nutrients for immediate growth (Chapin, 1980). However, here, all study species showed excess uptake in response to excess phosphorus supplied. The surplus nutrients can act as a bet hedging strategy against potential future shortage (Chapin et al., 1990) or play a role in functions other than (future) growth such as plant defence (Ågren, 2008). Luxury consumption can provide competitive 
advantage when species monopolise the available nutrients to the detriment of their competitors, a theory gaining empirical (see Van Wijk et al., 2003) and theoretical support (see de Mazancourt \& Schwartz, 2012). The luxury consumption in our experiment is probably a side effect of the nitrogen limitation that restricted plant growth, which caused the excess phosphorus to pile up in the tissue (especially for the acquisitive species).

\section{Low phosphorus concentrations in grasses}

Grass monocultures and grass-dominated communities had lower tissue phosphorus concentrations compared to forb monocultures and forb-dominated communities, consistent with previous empirical work (reviewed by (Güsewell, 2004)). There are several possible mechanisms that may explain this finding. First, grasses and forbs differ physiologically: (1) leaf growth in grasses is localised in the basal meristems, reducing phosphorus requirements for nucleic acids in the remaining part of the leaf (Halsted \& Lynch, 1996) and (2) the cation exchange sites of plant cell walls that regulate nutrient acquisition are less abundant in grasses compared to forbs (Haynes, 1980), which leads to lower concentrations of some nutrients in grasses compared with legumes and herbs (Marschner, 1995; Pirhofer-Walzl et al., 2011). Second, the grass monocultures and grass-dominated communities had a higher aboveground biomass than the forb monocultures and forb-dominated communities in our experiment. When plants grow and dry matter accumulation increases at a faster rate than phosphorus accumulation, phosphorus gets diluted in the tissue leading to lower tissue phosphorus concentration; the dilution effect (Jarrell \& Beverly, 1981). The presence of this dilution effect may also partly explain the lower phosphorus concentration in grasses and is confirmed by the clear negative effect of plant biomass on plant phosphorus concentration in both monocultures and mixtures. This dilution effect has been described in several other studies (Blondeel et al., 2019; Hejcman et al., 2010) and occurred independently of the soil phosphorus supply gradient in our experiment.

\section{Contrasting effect of nutrient use strategy on plant phosphorus concentration}

The species' or community's nutrient use strategy had no effect on plant phosphorus concentration when soil phosphorus supply was limiting. However, at high phosphorus supply, the plant phosphorus concentration responses in our experiment differed among species' nutrient use strategies. Hayes et al., 2014 also found an interaction between soil phosphorus and species' ecological strategy, with bigger differences in plant phosphorus concentrations between species of opposing nutrient-acquisition strategies when soil phosphorus is available in excess compared to when soil phosphorus is limiting.

In the monocultures, we found acquisitive grasses to have the highest tissue phosphorus concentrations at intermediate soil phosphorus supply, which is consistent with the growth rate hypothesis that states that leaves of acquisitive species contain more phosphorus-rich ribosomal RNA necessary for growth. High tissue phosphorus concentrations are an inevitable consequence of fast growth as growth rate is determined by the rate of protein synthesis. Nucleic acids can contain $30 \%$ of the total phosphorus content of a plant when the phosphorus supply is limiting. When phosphorus is supplied in excess, 
nutrient allocation patterns shift towards storage and metabolic non-active tissue may play a bigger role in explaining the measured plant phosphorus concentrations (Kerkhoff et al., 2006; Veneklaas et al., 2012). Plants grown at high soil phosphorus supply may accumulate inorganic phosphorus in the vacuoles (Hidaka \& Kitayama, 2011). This storage effect may be greater in slow-growing species compared to fast-growing ones (Chapin, 1980) which may explain our observation of conservative forbs having higher tissue phosphorus concentrations compared with acquisitive forbs. On top of that, the way we harvested our species may have contributed to this observation. We cut the aboveground biomass mimicking real-world harvesting in a mowing management; i.e. ca. $2 \mathrm{~cm}$ above ground level to allow vegetation regrowth, similar to most other (field) studies. For grasses, this implies that we mostly harvested the leaves (i.e., metabolically active tissue) while for the forbs, we harvested the whole plant including the structural tissue parts (i.e., the stems). This difference in the type of tissue that was harvested may, at least partly, explain the difference in the effect of nutrient use strategy on plant phosphorus concentration response between growth forms.

In the mixtures, we found no effect of the community's nutrient use strategy on plant phosphorus concentration at any of the phosphorus supply levels. Apparently, if species grow together in communities, the mean ecological strategy of the present species does not influence the vegetation tissue phosphorus concentration. We initially expected acquisitive communities to have higher tissue phosphorus concentrations compared to conservative communities, corresponding the growth rate hypothesis. As the conservative communities in our experiment showed an increase in biomass with soil phosphorus supply, dilution of the present phosphorus in the tissue at higher soil phosphorus supply levels may have been responsible for the similarity in plant phosphorus concentration in acquisitive and conservative communities.

\section{Implications}

Plant species vary in their ability to acquire, use and conserve nutrients (Reich 2003). We used the concept of the species' ecological strategy to study plant responses to soil phosphorus supply. In essence, a species' ecological strategy is a set of traits, i.e. a trait syndrome. We quantified the nutrient use strategy of a species by using the stress-tolerance value of the CSR framework which is based on actually measured leaf functional traits (StrateFy, Pierce et al. 2017). However, nutrient use is just one aspect of the ecological strategy of a species. For example, resource conservation and capture are equally important in the resource-limited environments, in which slow-growing species have evolved. Slow growth itself has no direct ecological advantage, but is part of a trait complex together with conservative use of nutrients (i.e. internal cycling and storage of nutrients) (Lambers \& Poorter, 1992). Due to the widespread and continued eutrophication of ecosystems worldwide, species with conservative nutrient use strategies are now at a disadvantage. They have become rare and endangered and are hence target species for restoration. We showed that species exhibiting a conservative nutrient use strategy may survive and even thrive in a situation of excess soil phosphorus availability. This finding is encouraging in the light of ecological restoration since our experiment mimics to some extent the restoration context of many grasslands in Western-Europe, i.e. having excess stocks of soil phosphorus from agricultural legacy 
and nitrogen limitation due to continued mowing or grazing management. It is, however, difficult to translate the findings from artificial experimental conditions to the field, among other things because establishment limitation was overcome by introduction of the species as equally sized seedlings planted at equal densities and because our pots did not allow for light competition. It is well-known that in eutrophic soils, fast-growing species generally outcompete slow-growing species due to light limitation (Hautier et al., 2009). Limitation by light may be minimized in the field with regular biomass removal (Jones et al. 2017). For example, a recent field study showed persistence of specialist plant species in high-phosphorus grasslands under a continued grazing management (Plue \& Baeten 2021).

\section{Conclusion}

We found that species exhibiting different ecological strategies responded differently to soil phosphorus supply, namely, in their tissue phosphorus concentrations and aboveground biomass. Adopting a traitbased approach enabled us to link findings from comparative ecological studies with insights from (eco)physiological research. Our findings contribute to the knowledge required for successfull ecological restoration of species-rich grasslands.

\section{Declarations}

\section{Acknowledgements}

We thank Luc Willems and Greet De bruyn for the chemical analyses of the soil and plant samples. We greatly thank our colleagues from ForNaLab and Remosa, lab technicians Kris Ceunen and Robbe De Beelde and HOGENT students for their help during the measurements in the greenhouse. Special thanks to Luc Willems and Kris Ceunen for their invaluable advice and practical assistance during the set-up and the measurements of the experiment. We kindly thank Dries Landuyt to provide a pre-submission review.

\section{Funding}

IM was funded by the Research Foundation Flanders (FWO) with a SB Grant (1S79521N).

\section{Conflicts of interest}

The autors declare there are no conflicts of interest

\section{Data and code availability}

Data will be made public via Figshare. Code is available from the authors upon request.

\section{Author contributions}

IM, LB, KV and SS conceived and designed the experiment; IM, MV, SS and ED planned and performed the data collection; IM analyzed the data and wrote the manuscript with input from all authors; LB, FVC and 
KV supervised the project; all authors provided critical feedback and helped shape the research, analysis and manuscript.

\section{References}

1. Aerts R, Chapin FS (1999) The Mineral Nutrition of Wild Plants Revisited: A Re-evaluation of Processes and Patterns. Adv Ecol Res 30(C):1-67. https://doi.org/10.1016/S0065-2504(08)60016-1

2. Ågren GI (2008) Stoichiometry and nutrition of plant growth in natural communities. Annual Review of Ecology, Evolution, and Systematics, 39(May 2021), 153-170. https://doi.org/10.1146/annurev.ecolsys.39.110707.173515

3. Bates D, Mächler M, Bolker BM, Walker SC (2015) Fitting linear mixed-effects models using Ime4. J Stat Softw, 67(1). https://doi.org/10.18637/jss.v067.i01

4. Blondeel H, Remy E, Perring MP, Landuyt D, Bodé S, De Frenne P, Boeckx P, Verheyen K (2019) Larger direct than indirect effects of multiple environmental changes on leaf nitrogen of forest herbs. Plant Soil 445(1-2):199-216. https://doi.org/10.1007/s11104-019-04298-1

5. Ceulemans T, Merckx R, Hens M, Honnay O (2011) A trait-based analysis of the role of phosphorus vs. nitrogen enrichment in plant species loss across North-west European grasslands. J Appl Ecol 48(5):1155-1163. https://doi.org/10.1111/j.1365-2664.2011.02023.x

6. Chapin FS (1980) The Mineral Nutrition of Wild Plants. Annu Rev Ecol Syst 11(1):233-260. https://doi.org/10.1146/annurev.es.11.110180.001313

7. Chapin FS, Schulze E, Mooney HA (1990) The Ecology and Economics of Storage in Plants. Annual Review of Ecology and Systematics, 21(1990), 423-447

8. Dayrell RLC, Arruda AJ, Pierce S, Negreiros D, Meyer PB, Lambers H, Silveira FA O (2018) Ontogenetic shifts in plant ecological strategies. Funct Ecol 32(12):2730-2741. https://doi.org/10.1111/13652435.13221

9. de Mazancourt C, Schwartz MW (2012) Starve a competitor: Evolution of luxury consumption as a competitive strategy. Theoretical Ecology 5(1):37-49. https://doi.org/10.1007/s12080-010-0094-9

10. Díaz S, Kattge J, Cornelissen JHC, Wright IJ, Lavorel S, Dray S, Reu B, Kleyer M, Wirth C, Prentice C, Garnier I, Bönisch E, Westoby G, Poorter M, Reich H, Moles PB, Dickie AT, Gillison J, Zanne AN, AE, ... Gorné, L. D (2016) The global spectrum of plant form and function. Nature 529(7585):167-171. https://doi.org/10.1038/nature16489

11. Dupouey JL, Dambrine E, Laffite JD, Moares C (2002) Irreversible impact of past land use on forest soils and biodiversity. Ecology 83(11):2978-2984. https://doi.org/10.1890/00129658(2002)083[2978:IIOPLU]2.0.C0;2

12. Elser JJ, Fagan WF, Kerkhoff AJ, Swenson NG, Enquist BJ (2010) Biological stoichiometry of plant production: Metabolism, scaling and ecological response to global change. New Phytol 186(3):593608. https://doi.org/10.1111/j.1469-8137.2010.03214.x 
13. Fox J, Weisberg S (2019) An R Companion to Applied Regression (3rd editio). Sage. https://socialsciences.mcmaster.ca/jfox/Books/Companion/index.html

14. Fujita Y, Venterink HO, Van Bodegom PM, Douma JC, Heil GW, Hölzel N, Jabłońska E, Kotowski W, Okruszko T, Pawlikowski P, De Ruiter PC, Wassen MJ (2014) Low investment in sexual reproduction threatens plants adapted to phosphorus limitation. Nature 505(7481):82-86. https://doi.org/10.1038/nature12733

15. Grime JP, ., Mason G, ., Curtis A. . V, Rodman J, ., Band S. R (1981) A Comparative Study of Germination Characteristics in a Local Flora. J Ecol 69(3):1017-1059

16. Grime JP (1977) Evidence for the Existence of Three Primary Strategies in Plants and Its Relevance to Ecological and Evolutionary Theory. Am Nat 111(982):1169-1194. https://doi.org/10.1086/283244

17. Güsewell S (2004) N:P ratios in terrestrial plants: Variation and functional significance. New Phytol 164(2):243-266. https://doi.org/10.1111/j.1469-8137.2004.01192.x

18. Halsted M, Lynch J (1996) Phosphorus responses of C3 and C4 species. 47(72), 2-3

19. Harpole WS, Tilman D (2007) Grassland species loss resulting from reduced niche dimension. Nature 446(7137):791-793. https://doi.org/10.1038/nature05684

20. Hautier Y, Niklaus PA, Hector A (2009) Competition for light causes plant biodiversity loss after eutrophication. Science 324(5927):636-638. https://doi.org/10.1126/science.1169640

21. Hayes P, Turner BL, Lambers H, Laliberté E (2014) Foliar nutrient concentrations and resorption efficiency in plants of contrasting nutrient-acquisition strategies along a 2-million-year dune chronosequence. J Ecol 102(2):396-410. https://doi.org/10.1111/1365-2745.12196

22. Haynes RJ (1980) Ion exchange properties of roots and ionic interactions within the root apoplasm: Their role in ion accumulation by plants. The Botanical Review 46(1):75-99. https://doi.org/10.1007/BF02860867

23. Hejcman M, Szaková J, Schellberg J, Tlustoš P (2010) The Rengen Grassland Experiment: Relationship between soil and biomass chemical properties, amount of elements applied, and their uptake. Plant Soil 333(1):163-179. https://doi.org/10.1007/s11104-010-0332-3

24. Hidaka A, Kitayama K (2011) Allocation of foliar phosphorus fractions and leaf traits of tropical tree species in response to decreased soil phosphorus availability on Mount Kinabalu, Borneo. J Ecol 99(3):849-857. https://doi.org/10.1111/j.1365-2745.2011.01805.x

25. Janssens F, Peeters A, Tallowin JRB, Bakker JP, Bekker RM, Fillat F (1998) Relationship between soil chemical factors and grassland diversity. Plant Soil 202:69-78.

https://doi.org/https://doi.org/10.1023/A:1004389614865

26. Jarrell WM, Beverly RB (1981) The dilution effect in plant nutrition studies. Adv Agron 34(C):197224. https://doi.org/10.1016/S0065-2113(08)60887-1

27. Jones L, Stevens C, Rowe EC, Payne R, Caporn SJM, Evans CD, ... Dale S (2017) Can on-site management mitigate nitrogen deposition impacts in non-wooded habitats? Biol Cons 212:464-475. https://doi.org/10.1016/j.biocon.2016.06.012 
28. Kerkhoff AJ, Fagan WF, Elser JJ, Enquist BJ (2006) Phylogenetic and Growth Form Variation in the Scaling of Nitrogen and Phosphorus in the Seed Plants. 168(4)

29. Klaus VH, Kleinebecker T, Hölzel N, Blüthgen N, Boch S, Müller J, Socher SA, Prati D, Fischer M (2011) Nutrient concentrations and fibre contents of plant community biomass reflect species richness patterns along a broad range of land-use intensities among agricultural grasslands. Perspectives in Plant Ecology Evolution Systematics 13(4):287-295. https://doi.org/10.1016/j.ppees.2011.07.001

30. Lajtha K, Driscoll C, Jarrell W, Elliott E (1999) Soil Phosphorus: Characterization and Total Element Analysis (Robertson). Oxford University Press

31. Lambers H, Poorter H (1992) Inherent Variation in Growth Rate Between Higher Plants: A Search for Physiological Causes and Ecological Consequences. Adv Ecol Res 34(03):283-362. https://doi.org/10.1016/S0065-2504(03)34004-8

32. Marrs RH (1993) Soil Fertility and Nature Conservation in Europe: Theoretical Considerations and Practical Management Solutions. In Advances in Ecological Research (Vol. 24, Issue C). https://doi.org/10.1016/S0065-2504(08)60044-6

33. Marschner H (1995) Mineral Nutrition of Higher Plants. In Mineral Nutrition of Higher Plants. https://doi.org/10.1016/b978-0-12-473542-2.x5000-7

34. Pierce S, Negreiros D, Cerabolini BEL, Kattge J, Díaz S, Kleyer M, Shipley B, Wright SJ, Soudzilovskaia NA, Onipchenko VG, van Bodegom PM, Frenette-Dussault C, Weiher E, Pinho BX, Cornelissen JHC, Grime JP, Thompson K, Hunt R, Wilson PJ, ... Tampucci D (2017) A global method for calculating plant CSR ecological strategies applied across biomes world-wide. Funct Ecol 31(2):444-457. https://doi.org/10.1111/1365-2435.12722

35. Pirhofer-Walzl K, Søegaard K, Høgh-Jensen H, Eriksen J, Sanderson MA, Rasmussen J, Rasmussen J (2011) Forage herbs improve mineral composition of grassland herbage. Grass Forage Sci 66(3):415-423. https://doi.org/10.1111/j.1365-2494.2011.00799.x

36. Plue J, Baeten L (2021) Soil phosphorous availability limits the contribution of small, individual grassland remnants to the conservation of landscape-scale biodiversity. Applied Vegetation Science

37. Pywell RF, Bullock JM, Tallowin JB, Walker KJ, Warman EA, Masters G (2007) Enhancing diversity of species-poor grasslands: An experimental assessment of multiple constraints. J Appl Ecol 44(1):8194. https://doi.org/10.1111/j.1365-2664.2006.01260.x

38. $\mathrm{R}$ Core Team (2021) R: A language and environment for statistical computing (version 4.0.4). $\mathrm{R}$ Foundation for Statistical Computing. https://www.r-project.org/

39. Reich APB, Wright IJ, Bares JC, Craine JM, Oleksyn J, Walters MB, Journal I, Reich PB, Westoby M (2003) The Evolution of Plant Functional Variation: Traits, Spectra, and Strategies. Evolution 164(S3):S143-S164

40. Reich PB (2014) The world-wide "fast-slow" plant economics spectrum: A traits manifesto. J Ecol 102(2):275-301. https://doi.org/10.1111/1365-2745.12211

41. Schelfhout S, Mertens J, Perring MP, Raman M, Baeten L, Demey A, Reubens B, Oosterlynck S, Gibson-Roy P, Verheyen K, De Schrijver A (2017) P-removal for restoration of Nardus grasslands on 
former agricultural land: cutting traditions. Restor Ecol 25:S178-S187.

https://doi.org/10.1111/rec.12531

42. Van Wijk MT, Williams M, Gough L, Hobbie SE, Shaver GR (2003) Luxury consumption of soil nutrients: A possible competitive strategy in above-ground and below-ground biomass allocation and root morphology for slow-growing arctic vegetation? J Ecol 91(4):664-676.

https://doi.org/10.1046/j.1365-2745.2003.00788.x

43. Veneklaas EJ, Lambers H, Bragg J, Finnegan PM, Lovelock CE, Plaxton WC, Price CA, Scheible WR, Shane MW, White PJ, Raven JA (2012) Opportunities for improving phosphorus-use efficiency in crop plants. In New Phytologist (Vol. 195, 2, pp 306-320). John Wiley \& Sons, Ltd.

https://doi.org/10.1111/j.1469-8137.2012.04190.x

44. Walker KJ, Stevens PA, Stevens DP, Mountford JO, Manchester SJ, Pywell RF (2004) The restoration and re-creation of species-rich lowland grassland on land formerly managed for intensive agriculture in the UK. Biol Cons 119(1):1-18. https://doi.org/10.1016/j.biocon.2003.10.020

45. Wassen MJ, Venterink HO, Lapshina ED, Tanneberger F (2005) Endangered plants persist under phosphorus limitation. Nature 437(7058):547-550. https://doi.org/10.1038/nature03950

46. White PJ, Hammond JP (2008) Phosphorus nutrition of terrestrial plants. In Springer (Ed.), The Ecophysiology of Plant-Phosphorus Interactions (pp. 51-81). https://doi.org/10.1007/978-1-40208435-5

47. Wickham H (2016) ggplot2: Elegant Graphics for Data Analysis. Springer-Verlag, New York. https://ggplot2.tidyverse.org

48. Wright IJ, Reich PB, Westoby M, Ackerly DD, Baruch Z, Bongers F, Cavender-Bares J, Chapin T, Cornellssen JHC, Diemer M, Flexas J, Garnier E, Groom PK, Gulias J, Hikosaka K, Lamont BB, Lee T, Lee W, Lusk C, ... Villar R (2004) The worldwide leaf economics spectrum. Nature 428(6985):821827. https://doi.org/10.1038/nature02403

49. Zuur AF, leno EN, Walker N, Saveliev AA, Smith GM (2009) Mixed effects models and extensions in ecology with R. Springer, New York. https://doi.org/doi:10.1007/978-0-387-87458-6

\section{Figures}



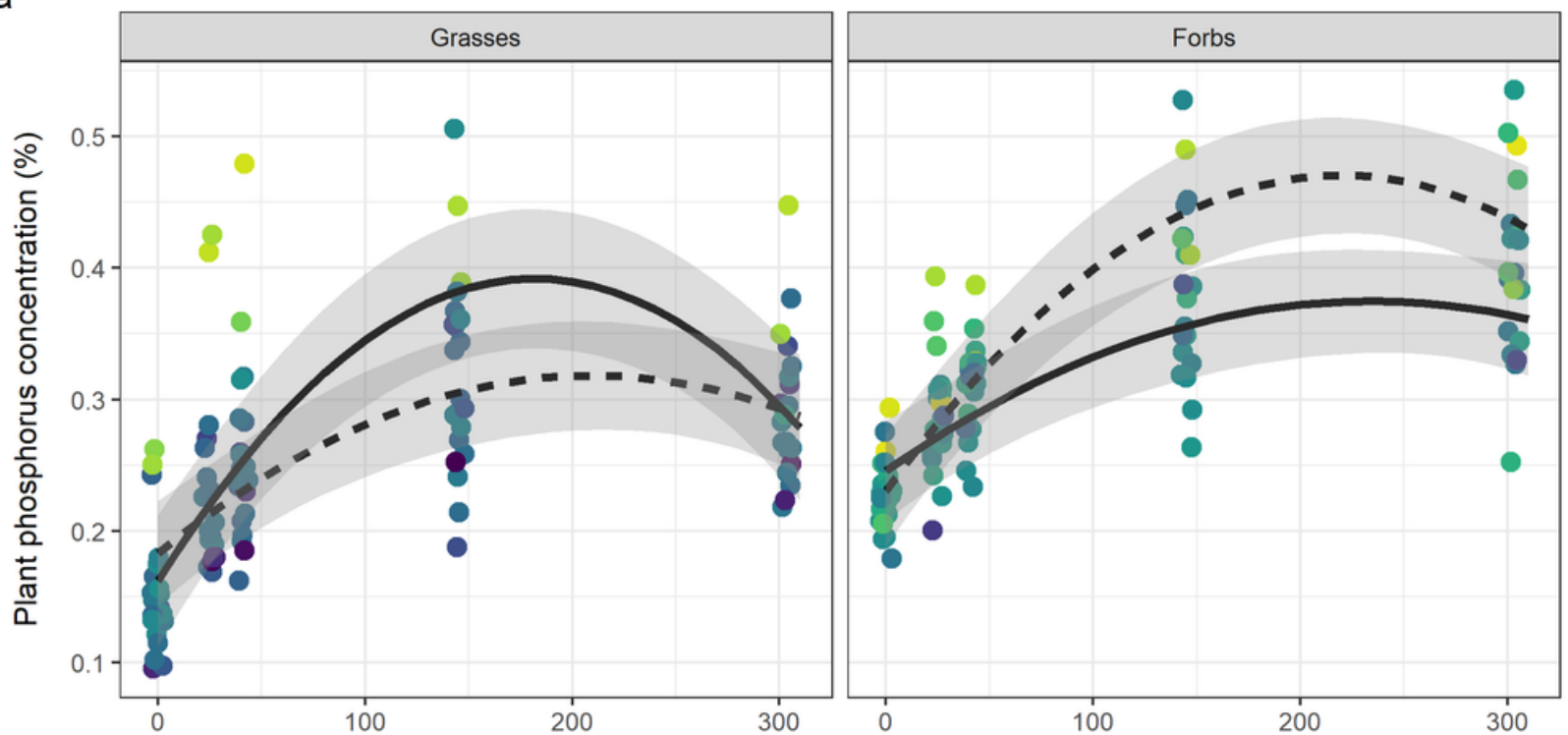

$S$ value

$-0$

… 60

Plant biomass $(\mathrm{g})$

b
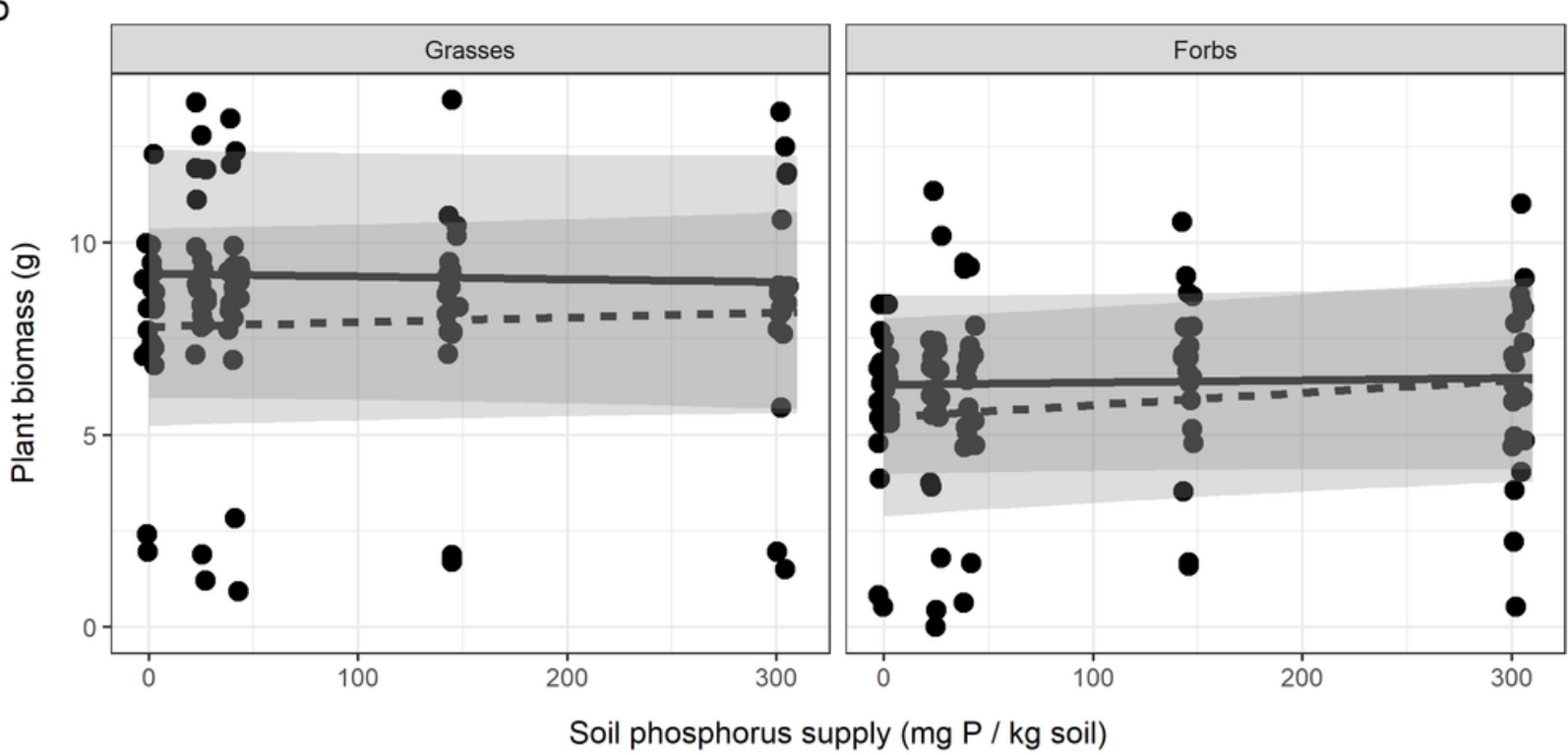

$S$ value

Soil phosphorus supply (mg P / kg soil)

\section{Figure 1}

MONOCULTURES - Effect of soil phosphorus supply on plant phosphorus concentration (a) and plant biomass (b). Jittered dots represent the observed data; lines represent model predictions for an acquisitive $(S=0)$ versus a conservative species $(S=60)$ of average biomass; ribbons represent the $95 \%$ prediction intervals. The full model specifications and the estimates can be found in the supplementary. 
a

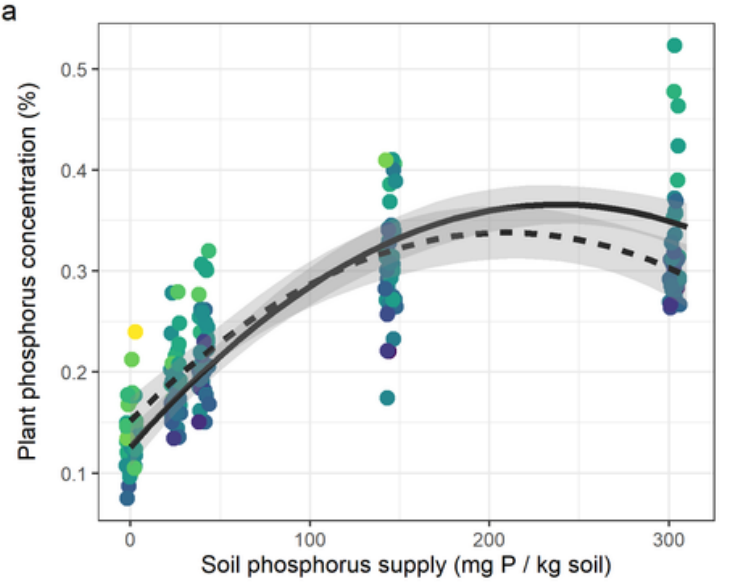

c

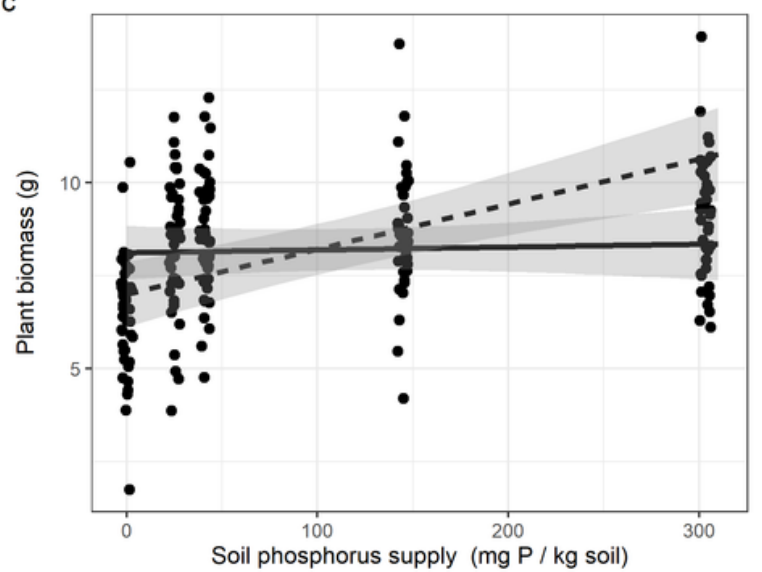

b

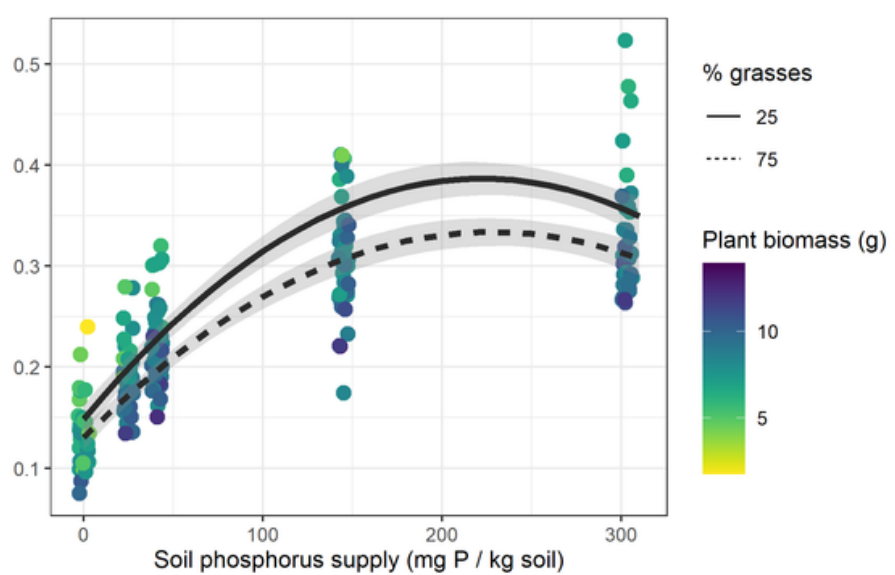

d

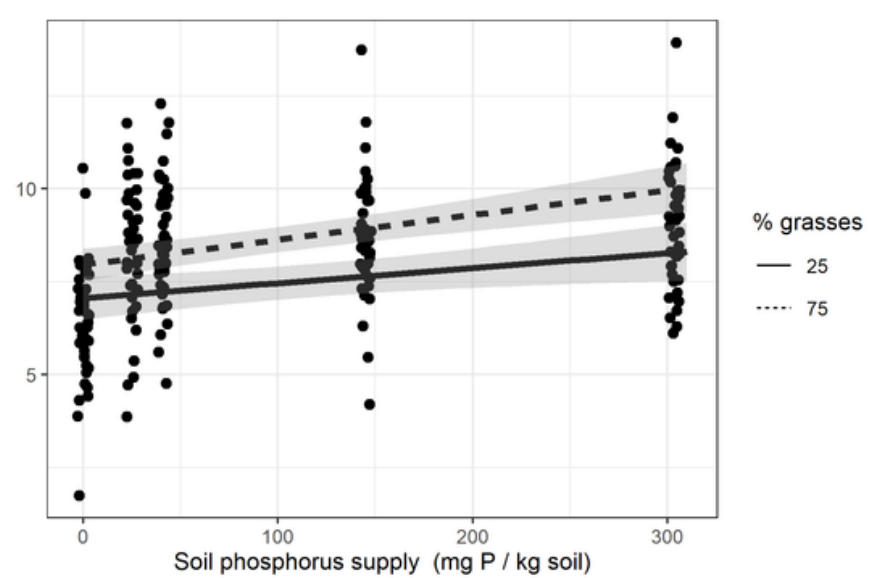

Figure 2

MIXTURES - Effect of soil phosphorus supply on plant phosphorus concentration $(a, b)$ and plant biomass $(c, d)$. Jittered dots represent the observed data, lines represent model predictions for acquisitive $(S=0)$ versus conservative communities $(S=60)(a, c)$ and communities dominated by forbs ( $25 \%$ grasses) or grasses (75\% grasses) $(b, d)$. All other explanatory variables of the model were kept average when making the model predictions (i.e.; mean biomass, $50 \%$ grasses or mean community $S$ value). Note that the observed data are the same for the left and right panels (with small variation due to the jitter); only the predictions differ. Ribbons represent the $95 \%$ prediction interval. The full model specifications and the estimates can be found in the supplementary.

\section{Supplementary Files}

This is a list of supplementary files associated with this preprint. Click to download.

- SllrisMoeneclaey.docx 